\title{
PENYULUHAN TENTANG PEMANFAATAN SAMPAH ORGANIK SEBAGAI KOMPOS DI KELURAHAN SELAGALAS KECAMATAN SANDUBAYA KOTA MATARAM
}

\author{
Ratna Yuniarti ${ }^{*}$, Muhammad Ismail, Hasyim, Rohani, Desi Widianty \\ Jurusan Teknik Sipil, Fakultas Teknik, Universitas Mataram \\ Jl. Majapahit Nomor 62 Mataram NTB \\ *A)Alamat Korespondensi: ratna_yuniarti@unram.ac.id
}

\begin{abstract}
ABSTRAK
Kelurahan Selagalas merupakan salah satu kelurahan yang berada di wilayah Kota Mataram. Sebagai bagian dari ibukota provinsi yang menjadi pusat kegiatan di Nusa Tenggara Barat, jumlah penduduk di kelurahan ini terus bertambah sehingga menghasilkan timbulan sampah yang semakin banyak. Sampah yang tidak dikelola secara efektif dan efisien akan menimbulkan berbagai permasalahan terhadap kesehatan, keindahan, kenyamanan dan menjadi beban bagi masyarakat serta pemerintah daerah. Agar dampak negatif yang ditimbulkan oleh sampah terhadap kesehatan dan lingkungan dapat diminimalkan, diperlukan peran serta masyarakat. Penyuluhan ini bertujuan memberikan pemahaman kepada masyarakat sehingga pengelolaan sampah dapat berjalan dengan baik. Penyuluhan yang berlangsung di Kelurahan Selagalas berjalan lancar sesuai dengan rencana yang telah ditetapkan serta menambah wawasan masyarakat tentang pemanfaatan sampah organik sebagai pupuk kompos.
\end{abstract}

Kata kunci: kompos, kelurahan Selagalas, sampah organik

\section{PENDAHULUAN}

Sebagai pusat pemerintahan, pendidikan, perdagangan dan berbagai kegiatan masyarakat di provinsi Nusa Tenggara Barat, jumlah penduduk yang berdatangan ke kota Mataram semakin bertambah. Dampak dari pertambahan penduduk tersebut adalah jumlah sampah yang dihasilkan semakin hari semakin meningkat. Jika seluruh sampah yang dihasilkan dikelola dengan cara mengangkut dan menimbunnya di tempat pembuangan akhir (TPA) sampah, maka TPA akan semakin cepat penuh dan dibutuhkan TPA baru untuk menggantikan TPA lama.

Menyediakan lahan baru yang cukup luas sebagai tempat 
penimbunan sampah bukan hal yang mudah. Sejumlah persyaratan teknis harus benar-benar dipenuhi agar tidak menimbulkan kerugian kelak di kemudian hari (Davis, 1998). Secara geologi, lokasi TPA harus stabil. Jika TPA terletak di lokasi yang rentan terhadap patahan, ribuan meter kubik sampah yang ditimbun berpotensi untuk longsor. Di samping itu, lokasi TPA juga harus bebas banjir, arah angin dominan tidak ke lokasi pemukiman, harus sesuai dengan perencanaan tata ruang kota, dan lainlain.

Mengingat luas wilayah yang tersedia adalah tetap sementara kebutuhan lahan untuk pemukiman dan berbagai kegiatan lainnya terus bertambah, peluang untuk mendapatkan lokasi TPA yang cocok semakin hari semakin sulit. Apabila digunakan lokasi yang cukup jauh, jarak dari sumber sampah ke lokasi TPA akan membuat ongkos angkut sampah menjadi mahal sehingga sulit dipenuhi oleh anggaran pemerintah daerah. Dari segi sosial, kendala lainnya untuk mencari lokasi TPA adalah penerimaan masyarakat. Karena nilai lahan di sekitar lokasi TPA cenderung menurun, tidah mudah bagi masyarakat untuk menerima keberadaan TPA di sekitar lokasi tempat tinggal mereka (Yuniarti, 2015).

Salah satu solusi untuk mengatasi hal tersebut adalah mengurangi jumlah sampah yang dikirim ke TPA sampai sekecil mungkin. Pengelolaan sampah tidak hanya dengan mengangkut dan menimbunnya di lokasi TPA, tapi mengolah sampah tersebut sesuai dengan karakteristik sampah yang bersangkutan (Tchobanoglous, 1993). Sampah organik yang berasal dari daun-daun sapuan jalan serta sampah dapur dapat dibuat kompos. Komposting didasarkan pada pengolahan sampah secara biologis sehingga dihasilkan bahan berbentuk humus yang dapat dimanfaatkan sebagai pupuk pertanian (Hartiningsih, 1989). 
Kelurahan Selagalas terletak di tengah-tengah kota Mataram dengan luas wilayah $\pm 288,89$ ha dan jumlah penduduk 13.082 jiwa (Anonim, 2016). Menurut data profil kelurahan Selagalas, beberapa kegiatan yang menjadi program kerja perangkat kelurahan antara lain adalah penyuluhan narkoba, penyuluhan demam berdarah serta penyuluhan manajemen koperasi wanita. Namun penyuluhan yang terkait dengan pengelolaan sampah masih belum dilakukan sehingga penanganan sampah masih belum optimal. Sebagian masyarakat masih menangani sampah yang dihasilkan dengan cara membakarnya di sekitar lahan pekarangan. Pembakaran sampah secara terbuka ini menimbulkan polusi udara dan berdampak merugikan bagi kesehatan (Sumaiku, 2003). Agar sampah dapat memberikan manfaat secara ekonomi (sampah sebagai sumber daya), sehat bagi masyarakat dan aman bagi lingkungan serta dapat mengubah perilaku masyarakat, maka penyuluhan terkait dengan kebiasaan masyarakat terhadap penanganan sampah perlu dilaksanakan.

\section{METODE KEGIATAN}

Khalayak sasaran kegiatan pengabdian kepada masyarakat adalah masyarakat di Kelurahan Selagalas Kecamatan Sandubaya Kota Mataram. Kegiatan pengabdian kepada masyarakat ini dilakukan dengan cara memberikan penyuluhan tentang materi-materi sebagai berikut:

1. Memberikan penyuluhan mengenai dampak negatif yang ditimbulkan oleh sampah terhadap kesehatan dan lingkungan.

2. Memberi penyuluhan tentang prinsip pengelolaan sampah dengan meng- utamakan proses pengurangan dan pemanfaatan sampah semaksimal mungkin serta TPA merupakan tahap terakhir penanganan sampah sesuai dengan prinsip solid waste management hierarchy .

3. Memberi penyuluhan tentang cara pengolahan sampah organik 
menjadi pupuk kompos dan pengabdian kepada masyarakat potensinya untuk meningkatkan kesejahteraan ekonomi masyarakat.

\section{HASIL DAN PEMBAHASAN}

Tahapan Pelaksanaan Kegiatan

$$
\text { Langkah pertama yang }
$$

dilakukan adalah melakukan survey di Kelurahan Selagalas Kecamatan Sandubaya Kota Mataram. Survey ini bertujuan untuk mendapatkan gambaran tentang permasalahanpermasalahan yang ada di kelurahan tersebut. Dari survey yang dilakukan, diketahui bahwa di kelurahan ini masih terdapat berbagai permasalahan mendasar antara lain adalah masih kurangnya partisipasi masyarakat dalam berbagai bidang pembangunan. Kurangnya partisipasi masyarakat tersebut termasuk dalam bidang persampahan. Di samping itu, permasalahan lainnya adalah masih lemahnya kelembagaan lingkungan maupun RT sehingga koordinasi dengan Kelurahan belum maksimal.

Sesuai dengan kesepakatan dengan perangkat desa, kegiatan 
dikirim ke TPA dapat diminimalkan. Hal krusial lainnya yang menjadi materi penyuluhan adalah pengolahan sampah organik menjadi pupuk kompos dan potensinya untuk meningkatkan pendapatan masyarakat.

\section{Dengan} memberikan pemahaman tersebut, diharapkan warga masyarakat ikut berpartisipasi untuk memelihara kebersihan lingkungan dan berperan aktif dalam mendukung program-program pemerintah untuk mengurangi jumlah sampah yang dikirim ke TPA sampai sekecil mungkin. Setelah penyampaian materi penyuluhan dilanjutkan dengan tanya jawab.

Hasil Pelaksanaan Kegiatan

Berdasarkan pengamatan yang dilakukan, terlihat bahwa masyarakat peserta penyuluhan mengikuti kegiatan ini dengan antusias terbukti dari banyaknya pertanyaan yang diajukan. Masyarakat dapat merasakan bahwa apa yang disampaikan memang perlu diterapkan demi kepentingan masyarakat sendiri. Sampah yang dikelola dengan baik dapat mengurangi berkembang biaknya lalat dan vektor pembawa penyakit sehingga kesehatan masyarakat menjadi lebih terjaga. Masyarakat juga diberikan pemahaman bahwa pembakaran sampah secara terbuka dapat menimbulkan polusi udara yang mengakibatkan berbagai penyakit gangguan saluran pernapasan. Menjaga agar saluran drainase dan sungai-sungai bebas dari sampah juga menjadi perhatian masyarakat dari pertanyaan yang diajukan. Dengan demikian dapat dikatakan bahwa umpan balik dari masyarakat terhadap kegiatan ini sudah sesuai harapan. Dari sisi tim penyuluh, kegiatan ini sudah mencapai sasaran karena terlaksananya salah satu unsur dari Tri Dharma Perguruan Tinggi yakni unsur Pengabdian kepada Masyarakat.

Kegiatan penyuluhan di Kelurahan Selagalas Kecamatan Sandubaya Kota Mataram tersebut disajikan pada Gambar berikut: 


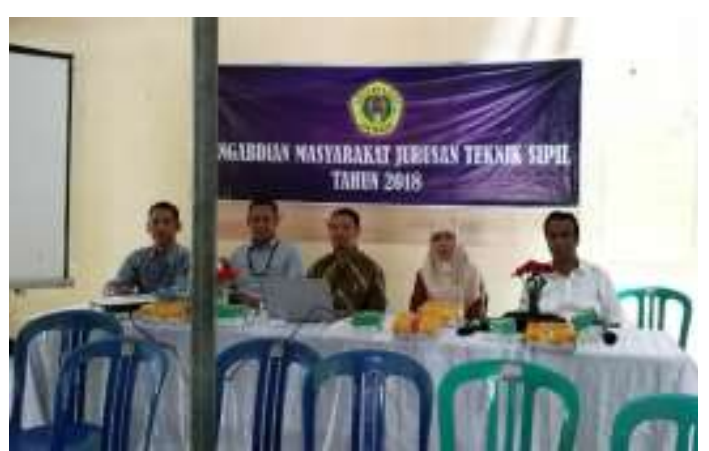

Gambar 1. Tim penyuluh

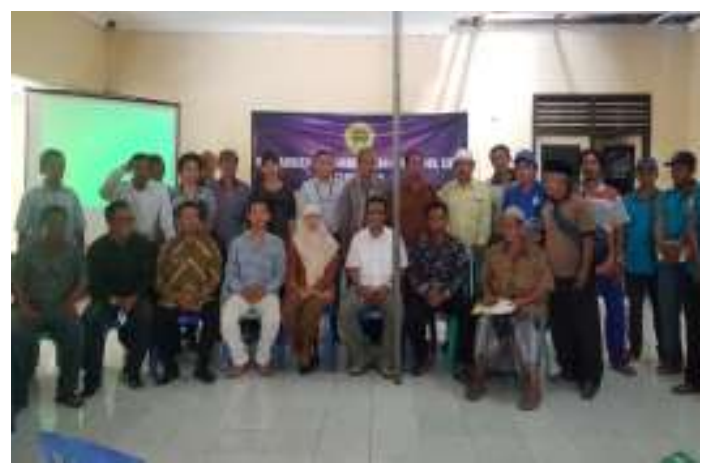

Gambar 2. Tim penyuluh beserta peserta penyuluhan

Faktor Pendukung dan Penghambat

Dalam melaksanakan kegiatan

ini, tim penyuluh tidak mengalami kendala yang berarti. Hal ini disebabkan karena koordinasi yang dilakukan dengan baik. Waktu pelaksanaan maupun lokasi kegiatan di kantor keluarahan Selagalas sudah dipersiapkan oleh aparat desa sehingga penyuluhan berjalan lancar.

$$
\text { Keberhasilan kegiatan }
$$

pengabdian kepada masyarakat ini tidak lepas dari dukungan berbagai pihak antara lain: (1) Dukungan dana dari Universitas Mataram cq. Lembaga Penelitian dan Pengabdian Kepada Masyarakat Universitas Mataram; (2) dukungan dari Jurusan Sipil dan Fakultas Teknik; (3) Dukungan Lurah dan jajaran staf pada Kelurahan Selagalas; (4) Semangat dan antusiasme yang tinggi dari peserta penyuluhan.

\section{Evaluasi}

Evaluasi dilakukan dengan melihat respon dan peran serta masyarakat peserta penyuluhan. Diharapkan apa yang disampaikan pada penyuluhan ini menjadi budaya masyarakat untuk mengelola sampah dengan baik untuk meminimalkan dampak negatif dari timbulan sampah tersebut. Pembuatan pilot project pengomposan juga diharapkan dapat dilaksanakan dengan dana desa yang relatif tidak besar dan mendapat dukungan swadaya masyarakat melalui gotong royong untuk kepentingan bersama.

\section{KESIMPULAN DAN SARAN}

\section{Kesimpulan}


Berdasarkan evaluasi yang

dilakukan dapat ditarik kesimpulan sebagai berikut:

1. Pelaksanaan penyuluhan telah berjalan lancar sesuai dengan waktu yang telah ditetapkan karena adanya dukungan dari pihak aparat kelurahan.

2. Warga masyarakat peserta penyuluhan mengikuti kegiatan dengan antusias karena banyaknya pertanyaan dan respon yang diberikan oleh peserta.

3. Kegiatan penyuluhan dapat memper-luas wawasan masyarakat tentang propek pemanfaatan sampah organik sebagai pupuk kompos, termasuk peluang usaha baru yang dapat diciptakan untuk meningkatkan kesejahteraan masyarakat.

\section{Saran}

1. Materi penyuluhan perlu ditindaklanjuti dengan aplikasi di lapangan misalnya dengan memanfaatkan dana desa untuk membuat pilot project pengomposan yang dapat menciptakan peluang usaha baru bagi masyarakat.

2. Penyuluhan ini perlu dilaksanakan di kelurahan atau desa-desa lain untuk meningkatkan pemahaman dan peran serta masyarakat agar sampah dapat dikelola dengan sebaik-baiknya.

\section{UCAPAN TERIMA KASIH}

Terima kasih disampaikan kepada Universitas Mataram cq. Lembaga Penelitian dan Pengabdian Kepada Masyarakat Universitas Mataram yang telah memberikan dukungan dana untuk melaksanakan kegiatan ini melalui dana DIPA BLU Universitas Mataram Tahun Anggaran 2018.

\section{DAFTAR PUSTAKA}

Anonim, 2016. Profil Kelurahan Selgalas, sipppid.mataramkota.go.id/file/ /profil-kelurahan-selagalas.

Davis, M.L.. 1998. Introduction to Environmental Engineering, McGraw-Hill, Singapore. Hartiningsih, dkk., 1989. Sampah dan Teknik Pengolahannya, Balai 
Teknik Kesehatan Lingkungan, Departemen Kesehatan, Jakarta.

Sumaiku, Y., 2003. Apa Akibatnya dari Pembakaran Sampah di Pekarangan Rumah Tangga dan Pembakaran / Kebakaran Hutan Terhadap Kesehatan, ww1.bpkpenabur.or.id/ kpsjkt/sehat/sampah.htm.
Tchobanoglous, G., et.al., 1993. Integrated Solid Waste Management, Engineering Principles \& Management Issue, McGraw-Hill, New York.

Yuniarti, R., 2015. Menyikapi Problema Sampah Kota Mataram, Harian Umum Lombok Post, 5-6 Juni 2015. 